\title{
Sudden Unexpected Death in Epilepsy (SUDEP): An Overview
}

\section{Epilepside Ani Beklenmedik Ölüm (SUDEP): Bir Gözden Geçirme}

\section{Torbjörn TOMSON, Olafur SVEINSSON}

Department of Clinical Neuroscience, Karolinska Institutet, and Department of Neurology, Karolinska University Hospital, Stockholm, Sweden

\section{Summary}

Sudden Unexpected Death in Epilepsy (SUDEP) has gained increased awareness over the last 2-3 decades. SUDEP is generally defined as the sudden, unexpected, witnessed or unwitnessed, non-traumatic, and non-drowning death in patients with epilepsy with or without evidence for a seizure, and excluding documented status epilepticus, in which postmortem examination does not reveal a structural or toxicologic cause for death. Sudden death is at least 20 times more common in people with epilepsy compared with the general population. The risk of SUDEP, however, varies widely within the epilepsy population, being the highest in patient with chronic treatment resistent epilepsy. There are probably a number of different mechanisms behind SUDEP, but most research has focused on seizure-related respiratory depression, cardiac arrhythmia, cerebral depression and autonomic dysfunction. Since the frequency of tonic-clonic seizures is the largest risk factor, effective treatment for epilepsy is the best prevention for SUDEP.

Key words: Sudden unexpected death in epilepsy; SUDEP; tonic-clonic seizures.

\section{Özet}

Son 20-30 yılda epilepside ani beklenmedik ölüm (Sudden Unexpected Death in Epilepsy - SUDEP) artan bir farkındalık kazanmıştır. SUDEP, postmortem incelemenin ölümün yapısal ve toksikolojik nedenini ortaya çıkartamadığı, belgelenmiş status epilepticus dışında kasılma nöbetleri kanıtları olan veya olmayan, genellikle ani, beklenmedik, tanık olunmuş veya olunmamış, travma ve boğulmaya bağlı olmayan ölüm olarak tanımlanmaktadır. Toplum geneline göre epilepsili kişilerde ani ölüm en azından 20 kez daha sık görülmektedir. Ancak SUDEP riski epileptik popülasyonda geniş ölçüde değişmektedir. İnatçı epilepsi için kronik tedavi alanlarda bu risk en yüksek düzeydedir. Olasılıkla SUDEP'in altta yatan birçok farklı mekanizması olmasına rağmen araştırmaların çoğu nöbetlerle ilişkili solunum baskılanması, kalp ritim bozuklukları, serebral depresyon ve anatomik işlev bozukluğuna odaklanmıştır. Tonik-klonik konvülsiyonların sıklığı en buyük risk faktörü olduğu için SUDEP'i önlemenin en iyi yolu epilepsinin etkili tedavisi olmaktadır.

Anahtar sözcükler: Ani beklenmedik ölüm; SUDEP; tonik-klonik konvülsiyon.

\section{Introduction}

Sudden Unexpected/Unexplained Death in Epilepsy (SUDEP) is a serious problem in epilepsy. This term refers to the occurrence of an unexpected death of a seemingly healthy person with epilepsy, usually in relation to a tonicclonic seizure, where no cause of death can be found. Although recognized since the 19th century, it has mainly been in the past two decades that the full extent and risk of SUDEP has been established and the need for increased awareness among physicians, patients and family members, as well as the public has become obvious.

SUDEP is by far the most common and important epilepsy related cause of death and its prevention of great concern for people with epilepsy and their families. The risk of dying
Submitted (Geliş): 25.09.2013

Accepted (Kabul): 09.10.2013

Correspondence (iletişim): Torbjörn TOMSON, M.D. e-mail (e-posta): torbjorn.tomson@karolinska.se 
suddenly and unexpectedly is more than 20 times higher among people with epilepsy compared with the general population. ${ }^{[1]}$ SUDEP has been estimated to account for a mean of $17 \%$ of deaths among people with epilepsy (range $4 \%$ to $40 \%$ ). ${ }^{[2]}$ The cumulative risk over the years for a person with epilepsy to die from SUDEP is significant. With a 40 year follow-up of population based cohort of people diagnosed with epilepsy in childhood, $9 \%$ had died in SUDEP. ${ }^{[3]}$ The life-time risk among people with chronic refractory epilepsy may be as high as $30-40 \%$. This being said, SUDEP can also occasionally occur in generally healthy people with less severe epilepsy.

Most SUDEP are unwitnessed, where assistance is not at hand. Many occur during sleep, and usually when the person is sleeping alone. A small number of definite SUDEP cases have been witnessed where at least $80 \%$ have been reported to have a seizure immediately before death. ${ }^{[4,5]}$ In all witnessed deaths, seizures terminated before death. Respiratory arrest (obstructive or central) was thought to be the cause of death in most witnessed cases.

\section{Definition(s) of SUDEP}

According to a definition proposed by Nashef ${ }^{[6]}$ SUDEP is the sudden, unexpected, witnessed or unwitnessed, nontraumatic, and non-drowning death in patients with epilepsy with or without evidence for a seizure, and excluding documented status epilepticus, in which postmortem examination does not reveal a structural or toxicologic cause for death. Cases fulfilling the above definition have been labelled "definite SUDEP"; sudden deaths occurring in benign circumstances with no known competing cause for death but without autopsy are classified as "probable SUDEP". Cases where SUDEP cannot be excluded, either because of limited information regarding death circumstances or there is a plausible competing explanation for death have been classified as "possible SUDEP" in a definition proposed by

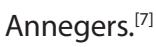

Slightly refined definitions have recently been proposed ${ }^{[8]}$ to resolve some ambiguities with previous definitions. This inovolves the introduction of the category of "SUDEP plus" where evidence indicates that a preexisting condition could have contributed to the death, which otherwise is SUDEP. Examples are coronary insufficiency or long-QT syndrome in a case of sudden unexpected death associated with a habitual epileptic seizure, but autopsy fails to reveal myocar- dial infarction or other structural causes of death. The creation of the SUDEP plus category provides the opportunity to investigate the role that these conditions have in causing SUDEP and whether treatment of the conditions could decrease the risk of these deaths.

It is also important to point out that negative findings of autopsy examination do not equate with a normal autopsy examination. Some degree of organ congestion, especially of the lungs, is commonly detectable at autopsy in cases of SUDEP, but not to a degree sufficient to cause acute death. Other findings may include evidence of a recent seizure, secondary anoxic changes, or underlying causes of the epilepsy. Autopsies vary considerably in their comprehensiveness and details in the historical information surrounding death, gross inspection of the body and organs, microscopic examination of tissues, and toxicologic and genetic studies.

Previous definitions have been rather vague in what is considered sudden, one group allowed for death to occur "within hours" of a terminal event. ${ }^{[9]}$ The new proposal has set an arbitrary time limit of one hour ${ }^{[8]}$ recognizing that deaths do not always occur instantaneously during the postictal phase. The proposal introduced the term "Near-SUDEP" for cases with a cardio-respiratory arrest where resuscitation reversed the condition so that the patient survived for more than one hour.

\section{Incidence of SUDEP}

The risk of SUDEP varies almost 100-fold, depending on the type of epilepsy population. The lowest incidence rates, 0.09 to $0.35 / 1,000$ person-years, have been reported from unselected cohorts of incident cases of epilepsy. ${ }^{[1,10]}$ Rates in chronic refractory epilepsy are between 1.1 to 5.9/1,000 person-years ${ }^{[9,11-14]}$ and in epilepsy surgery candidates or patients who continue to have seizures after surgery, 6.39.3/1,000 person-years. ${ }^{[15,16]}$ In patients with chronic refractory epilepsy attending epilepsy referral centers, SUDEP has been the leading cause of premature death accounting for $10-50 \%$ of all deaths. ${ }^{[9,17,18]}$

\section{Risk factors}

Why do some people die of SUDEP but not others? There is clearly an individual predisposition for SUDEP, and the reasons are likely to be multi factorial. Many epilepsy related, social, and lifestyle factors could contribute. The triggering 
factors that transform a seizure into a fatal event are also probably diverse.

Several retrospective case-control studies have analyzed risk factors for SUDEP. Due to the small samples with few included SUDEP cases in each study, it has been difficult to assess more than the strongest risk factors, and the precision of the risk estimates has been limited. To counteract these limitations, the ILAE Task Force on Epidemiology pooled data from four major case-control studies ${ }^{[19-22]}$ of SUDEP that adopted similar SUDEP criteria and all used living epilepsy patients as controls. ${ }^{[23]}$ This pooled analysis included altogether 289 SUDEP cases and 958 living epilepsy controls. The risk of SUDEP was found to be 1.4-fold higher in males compared to females, 1.7 fold higher in those with onset of their epilepsy at young age (before 16 years) compared to those with onset between 16 and 60 years, and two fold higher with those whose with a duration of epilepsy of more than 15 years. The most important risk factor was frequency of generalized tonic-clonic seizures (GTCS). Compared to people without GTCS, 1-2 GTCS/year was associated with an odds ratio (OR) of 2.94, 3-12 GTCS/year with OR of 8.28, and 13-50 GTCS/year OR of 9.06. The OR was 14.51 for those with $>50 \mathrm{GTCS} /$ year using seizure free as reference. It has been a consistent finding in almost all studies that the risk of SUDEP is higher in those patients who experience greater numbers of tonic-clonic seizures.

An important observation is the apparent protective effect of supervision. Unfortunately, this has so far been assessed in only one case-control study, in which regular checks during the night or use of a listening device was associated with a decreased risk (Odds Ratio, OR 0.1; 95\% Cl 0.0-0.3), as was sharing a bedroom with someone capable of giving assistance (OR 0.4;0.2-0.8). ${ }^{[21]}$ It was postulated ${ }^{[24]}$ that an accompanying person may stimulate (for instance by shaking) a person whose breathing has ceased, during or after a convulsive seizure, and this stimulation restores normal cardio-respiratory function; this is in our opinion a plausible supposition and may be particularly important in seizures occurring in sleep. Another case-control study identified nocturnal seizures as an additional risk factor associated with an OR of $2.6(1.3-5.0)^{[25]}$ which could fit with the previous observation of the importance of night-time supervision.

Pronounced and prolonged postictal EEG suppression has recently been proposed as an independent risk factor.
[26] Postictal flattening of EEG after a convulsive seizure recorded during epilepsy monitoring was significantly longer among 10 patients who on follow-up suffered SUDEP compared with surviving epilepsy controls. This prolonged cerebral inhibition might contribute to postictal respiratory dysfunction. A subsequent independent study, however, failed to confirm the association between prolonged postictal EEG-flattening and SUDEP risk, ${ }^{[27]}$ but suggested that this EEG-pattern is linked to GTCS, the latter in itself being the major risk for SUDEP.

Treatment with antiepileptic drugs (AEDs) has attracted particular attention as a risk factors as well as a possible SUDEP preventive measure. Since SUDEP in the vast majority of cases appears to be triggered by a seizure, it is reasonable to assume that an effective drug treatment would reduce the incidence of SUDEP. The analysis of pooled data from four case control studies also confirms that monotherapy with one AED is associated with a lower risk OR $0.5(95 \% \mathrm{CI}$ 0.3-0.99) compared with no treatment after adjustment for occurrence of GTCS. ${ }^{[28]}$

In further support of the preventive effect of AED treatment, poor compliance has frequently been suggested as a risk factor for SUDEP. ${ }^{[29-31]}$ Data are, however, so far somewhat conflicting which may relate to methodological problems with previous studies. ${ }^{[32]}$ In a retrospective cohort study, Faught and colleagues ${ }^{[33]}$ used Medicaid claims data to evaluate adherence to treatment in more than 33,000 patients with AED prescriptions. Non-adherence was associated with a more than threefold increase in overall mortality compared to adherence, with a hazard ratio of 3.32 (95\% Cl 3.1-3.5). Ridsdale and co-workers carried out a nested case-control study using data from the UK General Practice Research Database. ${ }^{[34]}$ A delayed collection of the last AED prescription was associated with increased mortality, Odds ratio 1.83 (1.66-2.03) However, the risk of SUDEP was unfortunately not analyzed separately in these two studies.

Some studies have suggested that polytherapy with AEDs is a risk factor for SUDEP. ${ }^{[14,19,20,35]}$ Polytherapy may, however, be a marker of severe epilepsy, and the combined analysis of four case-control studies found no increase in risk with polytherapy when adjustments included GTCS. ${ }^{[28]}$ In fact, a meta-analysis of randomized placebo-controlled clinical trials of add-on therapy with AEDs found the SUDEP incidence 
to be significantly lower among the patients that were randomised to active AED treatment as add-on compared with placebo. The odds ratio for SUDEP in active adjunctive vs. placebo add-on was $0.17(0.05-0.57) .{ }^{[36]}$ This indicated that in patients with drug resistant focal epilepsy adding a further AED may in fact reduce the risk of SUDEP probably by improving seizure control, at least under the rigorously controlled conditions of a clinical trial.

With respect to specific AEDs, two studies have reported a slight risk increase with use of carbamazepine ${ }^{[11,21]}$ and one in association with high plasma concentrations of carbamazepine. ${ }^{\left[{ }^{[3]}\right.}$ An uncontrolled case-series suggested an association between use of lamotrigine in idiopathic epilepsy and SUDEPP ${ }^{[38]}$ and a small case-control study from the same authors, including the four cases from the first publication, suggested an increased SUDEP risk in females using lamotrigine. ${ }^{[39]}$ Unfortunately this study did not adjust for GTCS, so one cannot exclude that the observed risk was due to poor seizure control with lamotrigine. In the combined analysis of four case-control studies, the association between lamotrigine use and SUDEP risk disappeared when adjustment was made for GTCS, and that analysis could not confirm an association between any specific AED and SUDEP risk. ${ }^{[28]}$

\section{Triggers and proposed mechanisms}

Although SUDEP is triggered by a seizure (GTCS) in most cases, the final event leading up to death is unclear and probably variable. ${ }^{[5]}$ Observations from witnessed SUDEPs and from cases that have died while under video-EEG monitoring suggest a prominent role of respiratory failure, central apnoea and hypoventilation ${ }^{[32]}$ but a few cases with asystole early in the sequence have also been described. The most frequently observed sequence of events seems to be a pronounced postictal suppression of EEG activity, accompanied by respiratory failure and cardiac asystole or arrhythmia as the final event. ${ }^{[32,40,41]}$ Factors predisposing an individual patient to SUDEP have been outlined in the previous section but mechanisms by which individual patients are susceptible to die from a seizure may also include genetic predispostion (e.g. Long-QT related mutations or impaired serotoninergic brain stem control of arousal and respiration), altered autonomic cardiac control, nocturnal (and presumably less surpevised) seizures, seizures with a pronounced postictal supression and respiratory compromise.

\section{Potential preventive strategies}

Given the present state of knowledge about risk factors and mechanisms, improved, and when possible complete, control of GTCS is the obvious strategy to prevent SUDEP. Pharmacological treatment should be optimized. This includes selection of the most appropriate AED for the patient's type of epilepsy, optimization of the dose, and measures to enhance compliance with the prescribed medication.

Successful epilepsy surgery appears to be associated with a reduced risk of SUDEP. A surgery series from Philadelphia including 583 patients reported 10 SUDEPs, none among the 256 that were seizure free since surgery. ${ }^{[16]}$ Likewise, none of the 6 SUDEP cases were seizure free in the follow-up of 596 patients in the population-based Swedish Epilepsy Surgery Registry. ${ }^{[15]}$ A series from Indiana USA reported 2 SUDEPs among 41 patients who continued to have seizures after surgery compared to $1 / 171$ seizure free patients. ${ }^{[42]}$ In a series from the UK, all 5 SUDEPs occurred in patients whose seizures were not fully controlled after surgery. There was no SUDEP among the 209 patients that were completely seizure free since surgery ${ }^{[43]}$ The Cleveland Clinic Epilepsy Centre identified 7 SUDEPs in patients that have undergone epilepsy surgery; none was seizure free at the time of death. [44] These data are intriguing, although the observations cannot be regarded as firm evidence for the effectiveness of epilepsy surgery in reducing the risk of SUDEP since there may be intrinsic differences between patients with favorable and unfavorable seizure outcome of surgery. ${ }^{[45]}$ Nevertheless, timely referral of suitable candidates to presurgical assessment might be important to reduce SUDEP risks.

Patient education is obviously important and should include information about the importance of adherence to treatment, and avoidance of seizure triggering factors. This highlights the sometimes controversial issue of informing about SUDEP. Surveys have indicated that many physicians are reluctant to talk to their patients about SUDEP concerned with the risk of causing stress and anxiety. ${ }^{[46]}$

It is our view that patients have the right to know and should have information about SUDEP, along the lines that 'although epilepsy is not usually a life-threatening condition, a small number of people do die in epileptic seizures from accidents and SUDEP, and that the risk can be minimized by controlling tonic-clonic seizures'. This information 
is best provided as part of a comprehensive counseling concerning risks and prevention in general.

\section{References}

1. Ficker DM, So EL, Shen WK, Annegers JF, O'Brien PC, Cascino $\mathrm{GD}$, et al. Population-based study of the incidence of sudden unexplained death in epilepsy. Neurology 1998;51(5):1270-4.

2. Hughes JR. A review of sudden unexpected death in epilepsy: prediction of patients at risk. Epilepsy Behav 2009;14(2):280-7.

3. Sillanpää M, Shinnar S. Long-term mortality in childhood-onset epilepsy. N Engl J Med 2010;363(26):2522-9. [CrossRef]

4. Kloster R, Engelskjøn T. Sudden unexpected death in epilepsy (SUDEP): a clinical perspective and a search for risk factors. J Neurol Neurosurg Psychiatry 1999;67(4):439-44. [CrossRef]

5. Langan Y, Nashef L, Sander JW. Sudden unexpected death in epilepsy: a series of witnessed deaths. J Neurol Neurosurg Psychiatry 2000;68(2):211-3. [CrossRef]

6. Nashef L. Sudden unexpected death in epilepsy: terminology and definitions. Epilepsia 1997;38:6-8. [CrossRef]

7. Annegers JF. United States perspective on definitions and classifications. Epilepsia 1997;38:9-12. [CrossRef]

8. Nashef L, So EL, Ryvlin P, Tomson T. Unifying the definitions of sudden unexpected death in epilepsy. Epilepsia 2012;53(2):227-33. [CrossRef]

9. Leestma JE, Annegers JF, Brodie MJ, Brown S, Schraeder P, Siscovick D, et al. Sudden unexplained death in epilepsy: observations from a large clinical development program. Epilepsia 1997;38(1):47-55. [CrossRef]

10. Lhatoo SD, Johnson AL, Goodridge DM, MacDonald BK, Sander JW, Shorvon SD. Mortality in epilepsy in the first 11 to 14 years after diagnosis: multivariate analysis of a long-term, prospective, population-based cohort. Ann Neurol 2001;49(3):336-44.

11. Timmings PL. Sudden unexpected death in epilepsy: a local audit. Seizure 1993;2(4):287-90. [CrossRef]

12. Nashef L, Fish DR, Sander JW, Shorvon SD. Incidence of sudden unexpected death in an adult outpatient cohort with epilepsy at a tertiary referral centre. J Neurol Neurosurg Psychiatry 1995;58(4):462-4. [CrossRef]

13. Klenerman P, Sander JW, Shorvon SD. Mortality in patients with epilepsy: a study of patients in long term residential care. J Neurol Neurosurg Psychiatry 1993;56(2):149-52. [CrossRef]

14. McKee JR, Bodfish JW. Sudden unexpected death in epilepsy in adults with mental retardation. Am J Ment Retard 2000;105(4):229-35. [CrossRef]

15. Nilsson L, Ahlbom A, Farahmand BY, Tomson T. Mortality in a population-based cohort of epilepsy surgery patients. Epilepsia 2003;44(4):575-81. [CrossRef]
16. Sperling MR, Harris A, Nei M, Liporace JD, O'Connor MJ. Mortality after epilepsy surgery. Epilepsia 2005;46 Suppl 11:49-53.

17. Mohanraj R, Norrie J, Stephen LJ, Kelly K, Hitiris N, Brodie MJ. Mortality in adults with newly diagnosed and chronic epilepsy: a retrospective comparative study. Lancet Neurol 2006;5(6):481-7. [CrossRef]

18. Racoosin JA, Feeney J, Burkhart G, Boehm G. Mortality in antiepileptic drug development programs. Neurology 2001;56(4):514-9. [CrossRef]

19. Nilsson L, Farahmand BY, Persson PG, Thiblin I, Tomson T. Risk factors for sudden unexpected death in epilepsy: a case-control study. Lancet 1999;353(9156):888-93. [CrossRef]

20. Walczak TS, Leppik IE, D'Amelio M, Rarick J, So E, Ahman P, et al. Incidence and risk factors in sudden unexpected death in epilepsy: a prospective cohort study. Neurology 2001;56(4):51925. [CrossRef]

21. Langan Y, Nashef L, Sander JW. Case-control study of SUDEP. Neurology 2005;64(7):1131-3. [CrossRef]

22. Hitiris N, Suratman S, Kelly K, Stephen LJ, Sills GJ, Brodie MJ. Sudden unexpected death in epilepsy: a search for risk factors. Epilepsy Behav 2007;10(1):138-41. [CrossRef]

23. Hesdorffer DC, Tomson T, Benn E, Sander JW, Nilsson L, Langan $Y$, et al. Combined analysis of risk factors for SUDEP. Epilepsia 2011;52(6):1150-9. [CrossRef]

24. Nashef L, Garner S, Sander JW, Fish DR, Shorvon SD. Circumstances of death in sudden death in epilepsy: interviews of bereaved relatives. J Neurol Neurosurg Psychiatry 1998;64(3):34952. [CrossRef]

25. Lamberts RJ, Thijs RD, Laffan A, Langan Y, Sander JW. Sudden unexpected death in epilepsy: people with nocturnal seizures may be at highest risk. Epilepsia 2012;53(2):253-7. [CrossRef]

26. Lhatoo SD, Faulkner HJ, Dembny K, Trippick K, Johnson C, Bird $J M$. An electroclinical case-control study of sudden unexpected death in epilepsy. Ann Neurol 2010;68(6):787-96. [CrossRef]

27. Surges R, Strzelczyk A, Scott CA, Walker MC, Sander JW. Postictal generalized electroencephalographic suppression is associated with generalized seizures. Epilepsy Behav 2011;21(3):2714. [CrossRef]

28. Hesdorffer DC, Tomson T, Benn E, Sander JW, Nilsson L, Langan $Y$, et al. Do antiepileptic drugs or generalized tonic-clonic seizure frequency increase SUDEP risk? A combined analysis. Epilepsia 2012;53(2):249-52. [CrossRef]

29. Téllez-Zenteno JF, Ronquillo LH, Wiebe S. Sudden unexpected death in epilepsy: evidence-based analysis of incidence and risk factors. Epilepsy Res 2005;65(1-2):101-15. [CrossRef]

30. Tomson T, Walczak T, Sillanpaa M, Sander JW. Sudden unexpected death in epilepsy: a review of incidence and risk factors. 2005;46 Suppl 11:54-61. 
31. Monté $\mathrm{CP}$, Arends JB, Tan IY, Aldenkamp AP, Limburg $M$, de Krom MC. Sudden unexpected death in epilepsy patients: Risk factors. A systematic review. Seizure 2007;16(1):1-7. [CrossRef]

32. Tomson T, Nashef L, Ryvlin P. Sudden unexpected death in epilepsy: current knowledge and future directions. Lancet Neurol 2008;7(11):1021-31. [CrossRef]

33. Faught E, Duh MS, Weiner JR, Guérin A, Cunnington MC. Nonadherence to antiepileptic drugs and increased mortality: findings from the RANSOM Study. Neurology 2008;71(20):1572-8.

34. Ridsdale L, Charlton J, Ashworth M, Richardson MP, Gulliford MC. Epilepsy mortality and risk factors for death in epilepsy: a population-based study. Br J Gen Pract 2011;61(586):271-8.

35. Beran RG, Weber S, Sungaran R, Venn N, Hung A. Review of the legal obligations of the doctor to discuss Sudden Unexplained Death in Epilepsy (SUDEP)-a cohort controlled comparative cross-matched study in an outpatient epilepsy clinic. Seizure 2004;13(7):523-8. [CrossRef]

36. Ryvlin P, Cucherat M, Rheims S. Risk of sudden unexpected death in epilepsy in patients given adjunctive antiepileptic treatment for refractory seizures: a meta-analysis of placebocontrolled randomised trials. Lancet Neurol 2011;10(11):961-8.

37. Nilsson L, Bergman U, Diwan V, Farahmand BY, Persson PG, Tomson T. Antiepileptic drug therapy and its management in sudden unexpected death in epilepsy: a case-control study. Epilepsia 2001;42(5):667-73. [CrossRef]

38. Aurlien D, Taubøll E, Gjerstad L. Lamotrigine in idiopathic epilepsy - increased risk of cardiac death? Acta Neurol Scand 2007;115(3):199-203. [CrossRef]

39. Aurlien D, Larsen JP, Gjerstad L, Taubøll E. Increased risk of sudden unexpected death in epilepsy in females using lamotrigine: a nested, case-control study. Epilepsia 2012;53(2):258-66.

40. So EL. What is known about the mechanisms underlying SUDEP? Epilepsia 2008;49 Suppl 9:93-8. [CrossRef]

41. Surges R, Thijs RD, Tan HL, Sander JW. Sudden unexpected death in epilepsy: risk factors and potential pathomechanisms. Nat Rev Neurol 2009;5(9):492-504. [CrossRef]

42. Salanova V, Markand O, Worth R. Temporal lobe epilepsy: analysis of failures and the role of reoperation. Acta Neurol Scand 2005;111(2):126-33. [CrossRef]

43. Bell GS, Sinha S, Tisi Jd, Stephani C, Scott CA, Harkness WF, et al. Premature mortality in refractory partial epilepsy: does surgical treatment make a difference? J Neurol Neurosurg Psychiatry 2010;81(7):716-8. [CrossRef]

44. Jehi L. Sudden death in epilepsy, surgery, and seizure outcomes: the interface between heart and brain. Cleve Clin J Med 2010;77 Suppl 3:S51-5. [CrossRef]

45. Persson H, Kumlien E, Ericson M, Tomson T. Preoperative heart rate variability in relation to surgery outcome in refractory epilepsy. Neurology 2005;65(7):1021-5. [CrossRef]

46. Morton B, Richardson A, Duncan S. Sudden unexpected death in epilepsy (SUDEP): don't ask, don't tell? J Neurol Neurosurg Psychiatry 2006;77(2):199-202. [CrossRef] 